\title{
EAl Endorsed Transactions

\section{Experimental system design for online characterization and performance analysis of PV module under distinguish environmental conditions}

\author{
Rahul Anand ${ }^{1}$, Yogesh K. Chauhan², Vinod Yadav³, and Rupendra Pachauri ${ }^{4 *}$ \\ ${ }^{1}$ Department of Electrical Engineering Department, Gautam Buddha University, Grater Noida, India- 201312 \\ ${ }^{2}$ Department of Electrical Engineering, Kamla Nehru Institute of Technology, Sultanpur, Uttar Pradesh, India- 228118 \\ ${ }^{3}$ Department of Electrical Engineering, Delhi Technological University, Delhi- 110042 \\ ${ }^{4}$ Department of Electrical and Electronics Engineering, School of Engineering, University of Petroleum and Energy Studies, \\ Dehradun, India- 248007
}

\begin{abstract}
This paper is a novel attempt to evaluate the performance of photovoltaic (PV) modules using current-voltage (I-V) and power-voltage (P-V) characteristics. Numerous significant performance parameters, such as open-circuit voltage, shortcircuit current, maximum power point (MPP), fill factor (FF) and efficiency, are evaluated under various environmental conditions during the investigation. In order to capture online solar electrical parameters, a low-budget test rig is developed using Arduino-assisted supporting components and interfaced with the MATLAB Graphical User Interface (GUI) environment to demonstrate experimental I-V and P-V characteristics. The performance assessment is conducted for three naturally available dust samples categorized using types and weights. In addition, reflectors are often used to boost the efficiency of clean and dusty modules for comprehensive comparison. The present study is useful for three aspects: designing a low-cost PV analyser; choosing the location of the solar power plant; and enhancing the efficiency of the current solar plant.
\end{abstract}

Keywords: photovoltaic system, dust samples, power losses, fill factor, dust effect.

Received on 14 March 2019, accepted on 20 March 2020, published on 23 March 2020

Copyright (C) 2020 Rahul Anand et al., licensed to EAI. This is an open access article distributed under the terms of the Creative Commons Attribution licence (http://creativecommons.org/licenses/by/3.0/), which permits unlimited use, distribution and reproduction in any medium so long as the original work is properly cited.

doi: 10.4108/eai.13-7-2018.163838

\section{Introduction}

Depleting fossil fuels and environmental concerns motivated researchers to explore and extract electrical energy from renewable energy resources. Solar energy is one of the promising renewable energy resources due to several associated advantages such as non-polluting green source, diverse technologies available, cost effectiveness, etc. I-V characteristic of the PV module is non-linear and is affected by several environmental parameters. Therefore measurement and acquisition of various environmental parameters and subsequent evaluation of solar PV performance is an important issue.
The authors [1], developed a low cost solar radiation measurement and data acquisition system based on the microcontroller. The designed system has features to easily obtain results from hardware and software. The developed system is used to monitor the PV plant and collect data at remote locations in the developed area. In [2], the authors designed an economic open source control system for realtime performance using remote signals and graphs. This microcontroller-based design is a low-cost open source hardware that can be used to provide better connectivity. The authors in [3], designed a data logger to size renewable energy sources and load solar-wind hybrid power system. In this paper, the solar-wind hybrid power generation records current and voltage for the purpose of analysis. The authors in [4] used Arduino and Raspberry-pi microcontroller to

*Corresponding author. Email: rpachauri@ddn.upes.ac.in 
design a wireless sensor controller. This wireless controller has been designed for a wide range of environmental monitoring applications. In [5], the authors designed an open source data logger to measure and record long environmental and operational data based on the Arduino platform. This data logger is designed to measure and analyse several useful parameters. The authors of [6], examined the impact of dust on the performance of PV modules in a given climate region. The weather elements mentioned in this paper depend on the season, which obviously affects the deposition of dust on PV modules. As a result, dust-induced PV performance is different in different seasons. The authors of [7] have established the effect of dust settlement on the power output of photovoltaic modules. In this paper, dust properties were examined by means of a scanning electron microscope (SEM). Special PV glass coating has potential power loss reduction caused by dust settlement. In [8], the authors have reported the results of a study on the effect of dust accumulation on solar PV module power output. The study shows that power decreases by as much as half of the real power of the PV module. Basically, the decrement in power output due to dust accumulation depends not only on the duration of the module exposure, but also on the properties of dust. In terms of electrical parameters and PV characteristics, the authors of [9] investigated the various effects of dust deposition on PV panel glazing. Several types of dust samples were considered for this purpose. Studies on the effect of different environmental parameters on the efficiency and performance of PV cells were conducted by the authors in [10]. Dust settling on the surface of the PV module reduces power and efficiency. The authors of [11] discuss experiments on the impact of dust deposition on the performance of the solar system. There are other dependent factors that can be accounted for in terms of efficiency and output to verify system performance. In [12], the authors have monitored the PV modules ' real - time temperature, power generation, solar irradiance and other environmental parameters. Dust deposition strongly affects the performance of PV modules. In [13], the authors have studied the effect of dust on PV modules performance. Due to the deposition of different types of pollutants and accumulations, reduced PV performance was identified. In addition, the type of dust that has more effect on the voltage of the PV module has been identified. The authors of [14] aimed at identifying the deposition of seasonal dust on a large-scale PV plant. Preventing dust deposition at the PV module plant improves the frequency level of the plant and provides good efficiency. The authors of [15] studied the effect of dust fouling on the glass coverage of the PV module and investigated the effect on dust mitigation of the inclination angle and anti - reflective cover. The results concluded that these effects reduce the required efficiency and power output. The authors of [16] studied the effect of dust on the PV module's light transmission. Analyse the effect of dry cleaning on glass removal of settled dust particles and the impact of brushing on glass transmission. Soft clothes brushes and brushes with longer bristles to further investigate the cleaning efficiency and related impact on the panel and prevent damage to the solar panel surface. The authors of [17] studied that accumulated dust reduces solar panel performance and reduces solar panel efficiency. The authors [18] studied the effect of external and internal reflectors on both sides. Reflectors are good modifications to increase solar irradiation and efficiency. The authors of [19] used the bifacial solar panel with the optimized reflector and achieved maximum power and efficiency. The solar panel thus obtained has good current and voltage performance. The authors of [20] reported the accumulation of dust and soil that reduces reflectance radiation, solar field efficiency, and optimized the cost of cleanliness. In [21], the authors have analysed and compared the solar panel without a reflector, solar radiation and different reflector angle. As a result, the solar efficiency increases when the reflector angle is adjusted. After evaluating the power output, the authors of [22] investigated and analysed the performance of mono-crystalline using concentrator and reflector. A performance improvement has been claimed in this paper, which prevents the fluctuating intensity of sunlight due to the passing of different cloud conditions and other factors such as temperature and humidity. The authors [23] discuss with a semi-concentration reflector the structural and economic benefit of spherical silicon solar cell. This demonstrates improved solar cell electrical performance and provides a good level of intensity. The authors [24] used planar concentrator as a low - cost method to increase the solar panel's performance and efficiency. It is possible to use this methodology to optimize the reflector topology and to identify the increased energy.

The novel addition in this paper, with the inspiration of the above-mentioned literature, is to establish a budget experimental set-up for online PV module characterizations required to assess the impact of considered natural soils, namely Brick furnace dust, Sugar mill bagasse dust, Natural dust. Performance is also measured using aluminium reflectors with a touch of improvement.

\section{Experimental setup and specifications}

The real-time system comprises of different components, for example, two Arduino (ATmega328P, ATmega16U2), Temperature-humidity Sensor Module (DHT11), Photo resistor Light sensor (VEE00067), Current sensor (ACS712: Range-25A), and Voltage sensor module (KG045). A monocrystalline PV module comprises $4 \times 4$ solar cells in parallel series for online PV module characterization. The schematic and experimental diagrams include various important components, as shown in Figure 1, 


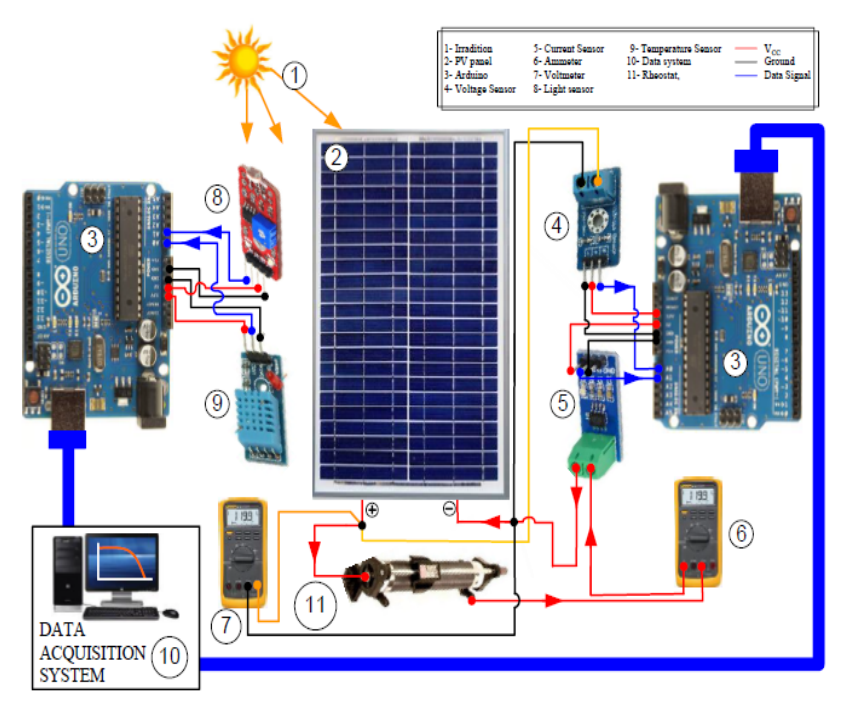

Figure 1. Schematic diagram of system under consideration

\subsection{Specification of system components}

The specifications of all the associated components in the experimental setup are listed as,

\section{Arduino (Atmega 328)}

- Microcontroller Atmega- 328, Operat. Voltage= $+5 \mathrm{~V}$.

- Digital output Pins: 14 (of which 6 provide PWM output)

- Analog input pins: 6

- DC current per output pin: $40 \mathrm{~mA}$

○ DC current for $3.3 \mathrm{~V}$ pin: $50 \mathrm{~mA}$

- Memory: Flash memory- $32 \mathrm{~KB}$ out of which 0.5 KB used by boot loader, SRAM- $2 \mathrm{~KB}$ and EEPROM- $1 \mathrm{~KB}$

- Clock speed: $16 \mathrm{MHz}$

\section{Photo-resistor Light sensor}

I/P voltage: $3.3-6 \mathrm{~V} \mathrm{DC}$

- Supply current $-0.5-3 \mathrm{~mA}$

$\circ$ Sense irradiation range $0-1023 \mathrm{~W} / \mathrm{m}^{2}$

$\circ$ Peak wavelength $-540 \mathrm{~nm}$

\section{Temperature and Humidity sensor}

○ Power supply: 3-5.5V DC Output signal- digital signal via single- bus sensing element

- Polymer resistor measuring range- humidity

- $20-90 \% \mathrm{RH}$

○ Temperature $0-50^{\circ} \mathrm{C}$ humidity hysteresis

$\circ \quad \pm 1 \% \mathrm{RH}$
○ Long-term stability: $\pm 0.5 \% \mathrm{RH} /$ year

- Sensing period average: $2 \mathrm{sec}$.

\section{Current sensor}

○

Current sensor chip: ACS712ELC-05B

Pin +5 V DC supply, on board indicator

\section{Voltage sensor}

○ I/P DC voltage range: $0-25 \mathrm{~V}$

○ DC voltage detection range: $0.02445 \mathrm{~V}-25 \mathrm{~V}$

- Voltage analog resolution- $0.00489 \mathrm{~V}$

O Output interface: "+" then 5/3.3V, "-" then GND, "s" then the A0 pin

$\circ \quad+5 \mathrm{~V}$ maximum voltage on the ADC side of the module

For the purpose of designed system investigation, a selfassembled $4 \times 4$ series-parallel (SP) configured module is developed. The area of PV cell is $0.316 \mathrm{~m}^{2}$. The experimental setup of designed system is shown in Figure 2 as,

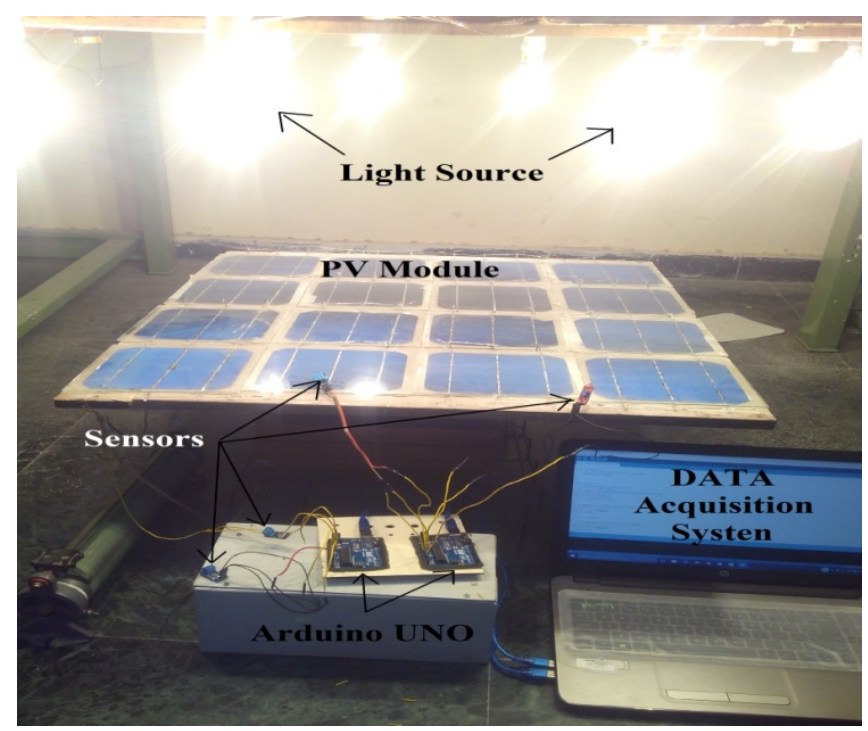

Figure 2. Experimental setup for investigation

\section{Results and discussion}

The real time measured voltage and current are used to obtain power, efficiency and FF of PV module with the resistive load variation. Several test cases are considered for performance investigation. The characteristics of I-V and P-V are plotted for various test cases as follows:

- Performance of clean PV module with and without reflector

- Effect of various types of dust accumulation on PV performance without reflector 
- Effect of various types of dust accumulation on PV performance with reflector

- Performance comparison of all the considered above cases

\subsection{PV performance of clean $\mathrm{PV}$ module with and without reflector}

This section discusses about effect with and without reflector on the PV module. The reflector increases the intensity of light falls on PV module. Aluminium foil material is used for reflecting purpose and the reflecting properties depend on the size and optical properties of the used reflector. Optical properties of Aluminium (AL) reflector is, Refractive index $(\mathrm{n}=1.0972)$, Extinction coefficient $(\mathrm{K}=6.7943)$, Chromatic dispersion $\left(3.5414 \mu \mathrm{m}^{-1}\right)$ and area of reflector is $\left(\mathrm{A}=0.38 \mathrm{~m}^{2}\right)$. In order to get more solar energy and increase short circuit current $\left(\mathrm{I}_{\mathrm{sc}}\right)$, four aluminium sheet made reflectors are mounted on the side of PV module and light source is fitted vertical over the PV module to avoid shadow. The experimental setup of clean PV module with reflector shown in Figure 3 as,

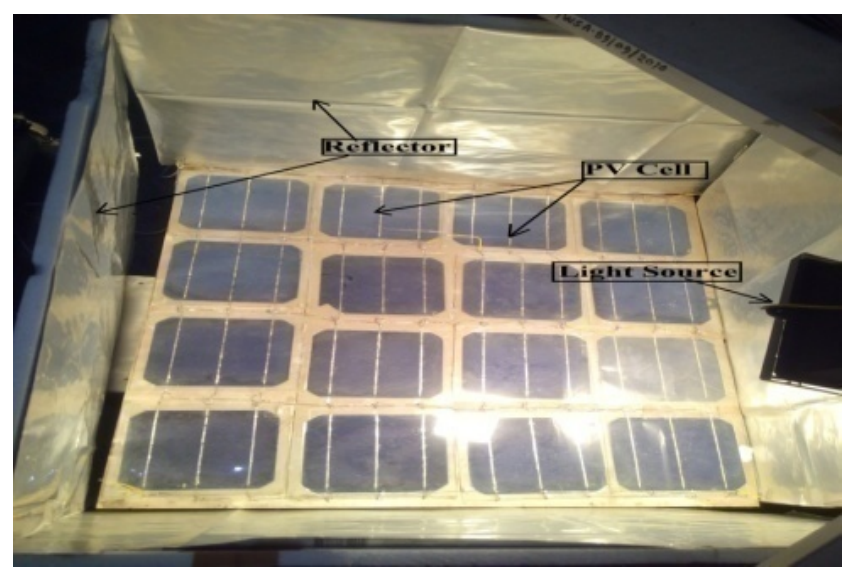

Figure 3. Experimental setup of clean PV module with reflector

The voltage of the open circuit and the current of the short circuit increases with the increase in solar irradiance, thus varying the maximum power point. The PV module performance is obtained at different levels of irradiance. For the given irradiation level, voltage, current, power, efficiency and $\mathrm{FF}$ are calculated and maximum power is obtained for the given voltage. The corresponding characteristics of I-V and $\mathrm{P}-\mathrm{V}$ indicate the $\mathrm{P}_{\max }$ for different levels of irradiance. The power output of the PV module is obtained as high at high irradiance level. The characteristics of I-V and P-V are plotted with and without a clean module reflector and are shown in Figures 4 and 5.

In Figure 4 the $\mathrm{I}-\mathrm{V}$ and $\mathrm{P}-\mathrm{V}$ curves are shown at the irradiation level of 300 and $500 \mathrm{~W} / \mathrm{m} 2$. These results are used for calculating the FF, power and efficiency of PV module, needed for comparison study. The electrical parameters of PV module without reflector at different irradiation level $(300 / 500 \mathrm{~W} / \mathrm{m} 2)$ are shown in Table 1.

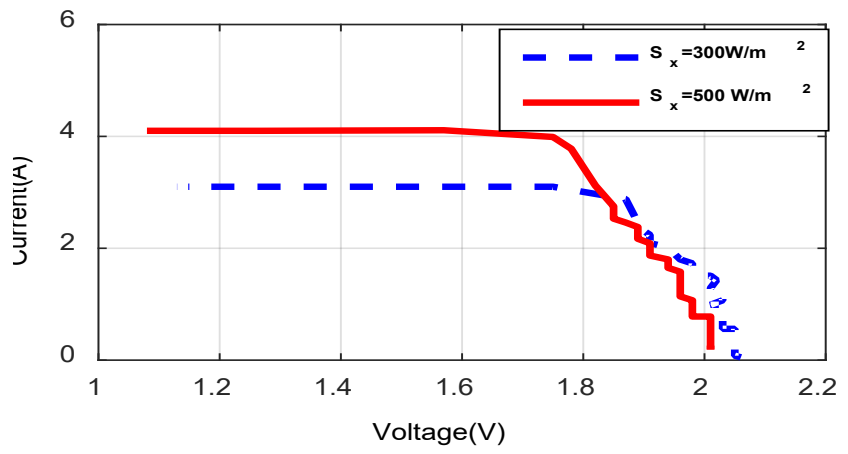

(a) I-V characteristics

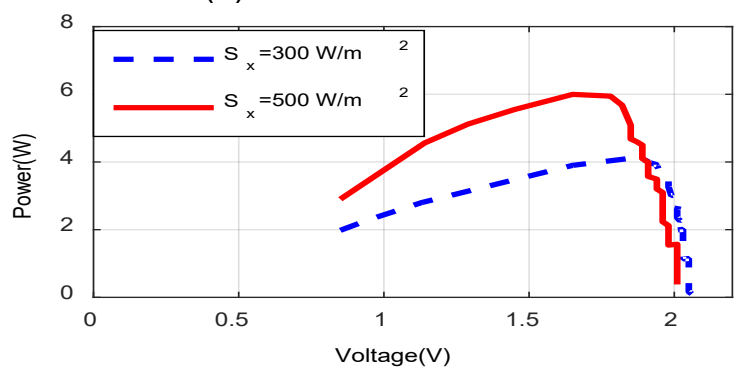

(b) P-V characteristics

Figure 4. $\mathrm{I}-\mathrm{V}$ and $\mathrm{P}-\mathrm{V}$ characteristics of clean $\mathrm{PV}$ module without reflector

Table 1. Electrical performance parameters of clean $\mathrm{PV}$ module without reflector

\begin{tabular}{lcc}
\hline \multirow{2}{*}{ Performance parameters } & \multicolumn{2}{c}{ Irradiation level } \\
\cline { 2 - 3 } & $500 \mathrm{~W} / \mathrm{m}^{2}$ & $300 \mathrm{~W} / \mathrm{m}^{2}$ \\
\hline $\mathrm{V}_{\mathrm{oc}}(\mathrm{V})$ & 2.08 & 2.08 \\
$\mathrm{I}_{\mathrm{sc}}(\mathrm{A})$ & 4.10 & 3.10 \\
$\mathrm{I}_{\mathrm{m}}(\mathrm{A})$ & 3.92 & 2.94 \\
$\mathrm{~V}_{\mathrm{m}}(\mathrm{V})$ & 1.75 & 1.73 \\
Power $(\mathrm{W})$ & 5.94 & 4.13 \\
$\mathrm{FF}$ & 0.80 & 0.78 \\
${ }^{*}$ Efficiency (\%) & 3.70 & 2.74 \\
\hline
\end{tabular}

artificial light source as Helogen lamp is another reason

In Figure 5, the I-V and P-V characteristics at different irradiation level of $500 / 300 \mathrm{~W} / \mathrm{m}^{2}$ are shown with reflectors. For obtaining maximum power and efficiency of the PV module, the aluminum reflectors are used at all the four sides. Due to this effect, increment in short circuit current $\left(\mathrm{I}_{\mathrm{sc}}\right), \mathrm{V}_{\mathrm{m}}$ and $\mathrm{I}_{\mathrm{m}}$ of the PV module resulted. These results are used to calculate the FF, power and efficiency of PV module. The electrical performance parameters of $\mathrm{PV}$ module with reflector at different irradiation level $\left(500 / 300 \mathrm{~W} / \mathrm{m}^{2}\right)$ are depicted in Table 2 as, 


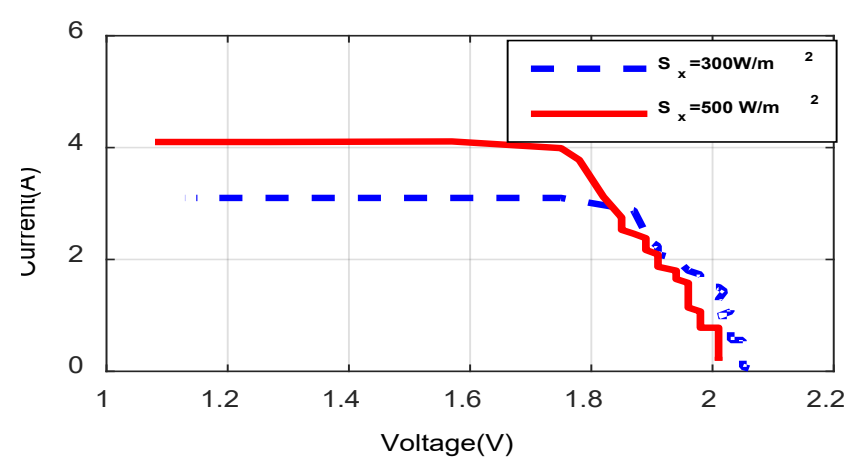

(a) I-V characteristics

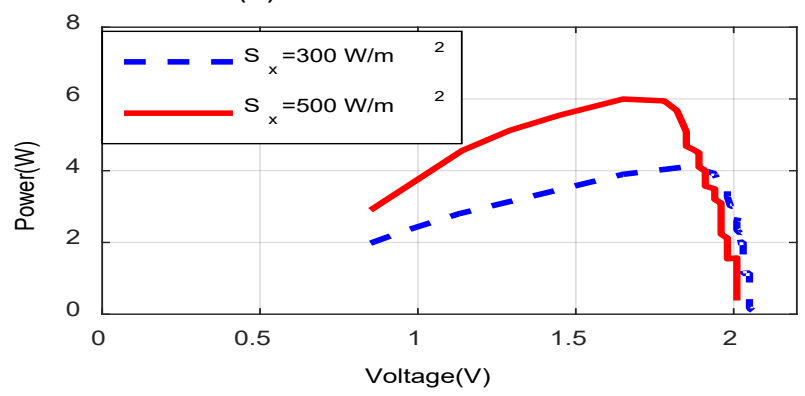

(b) P-V characteristics

Figure 5. I-V and P-V characteristics of clean module with reflector

Table 2. Electrical performance parameters of clean PV module with reflector

\begin{tabular}{lcc}
\hline \multirow{2}{*}{ Performance parameters } & \multicolumn{2}{c}{ Irradiation levels } \\
\cline { 2 - 3 } & $500 \mathrm{~W} / \mathrm{m}^{2}$ & $300 \mathrm{~W} / \mathrm{m}^{2}$ \\
\hline $\mathrm{V}_{\mathrm{oc}}(\mathrm{V})$ & 2.10 & 2.10 \\
$\mathrm{I}_{\mathrm{sc}}(\mathrm{A})$ & 6.22 & 5.52 \\
$\mathrm{I}_{\mathrm{m}}(\mathrm{A})$ & 6.15 & 5.12 \\
$\mathrm{~V}_{\mathrm{m}}(\mathrm{V}) \mathrm{S}$ & 1.81 & 1.51 \\
Power (W) & 10.13 & 7.47 \\
$\mathrm{FF}$ & 0.85 & 0.69 \\
Efficiency (\%) & 6.01 & 5.25 \\
\hline
\end{tabular}

\subsection{Effect of various types of dust accumulation on PV module performance without reflector}

This section examines the effect of accumulating different types of dust on the surface of the PV module. The dust deposits on the surface of the PV module emulate the scenario under real environmental conditions. Dust obstructs the irradiation that has entered the solar cell and reduces the power generated. In this case, the degradation of PV performance using various types of dust was investigated under different levels of irradiance. For investigation purpose, Brick furnace dust, Sugarcane mill dust and Natural dust are considered. The weights of all the dust samples are measured by digital weighing machine. The dust samples' weights (1gm, $2 \mathrm{gm}$ and $5 \mathrm{gm}$ ) of each dust sample have been taken for investigation purpose. Figure 4 shows the sample of all the three types of dust as,

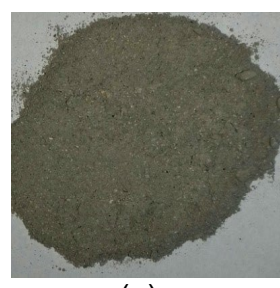

(a)

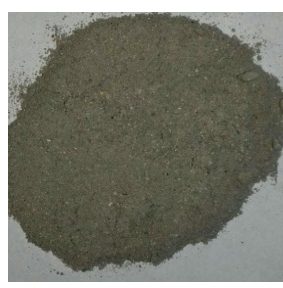

(b)

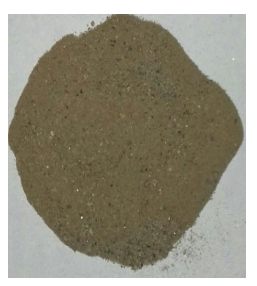

(c)
Figure 6. Sample of different types of dusts: (a) Brick furnace dust (b) Sugar mill bagasse dust (c) Natural dust

\subsubsection{Effect of Brick furnace dust on PV module performance}

The brick furnace dust sample is weighed as $1 \mathrm{gm}, 2 \mathrm{gm}$ and $5 \mathrm{gm}$ and spread almost uniformly over the PV module. The electrical performance parameters are analysed for all the samples of weights at two levels of the irradiation. The effect of dust accumulation is causing reduction in short circuit current $\left(\mathrm{I}_{\mathrm{SC}}\right)$. The solar irradiation incident to the PV module decreases the output strength of the PV module due to the dust of the brick furnace and the performance of the system to be decreased. The characteristics of I-V and P-V are plotted for brick furnace dust at different weights and the irradiation and efficiency characteristics are shown in Figure 7-8 as,

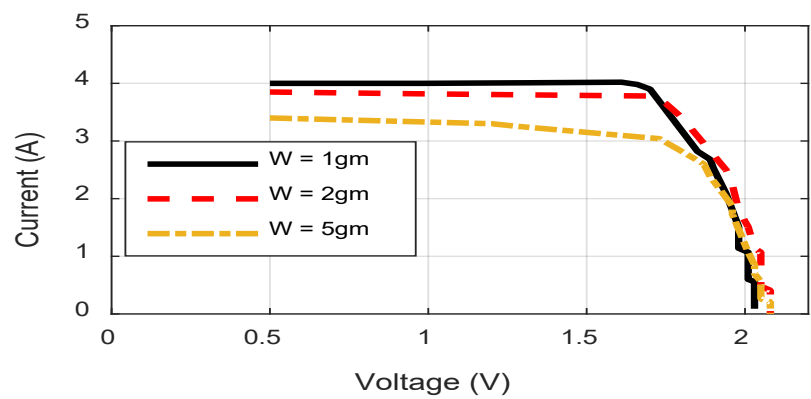

(a) I-V characteristics

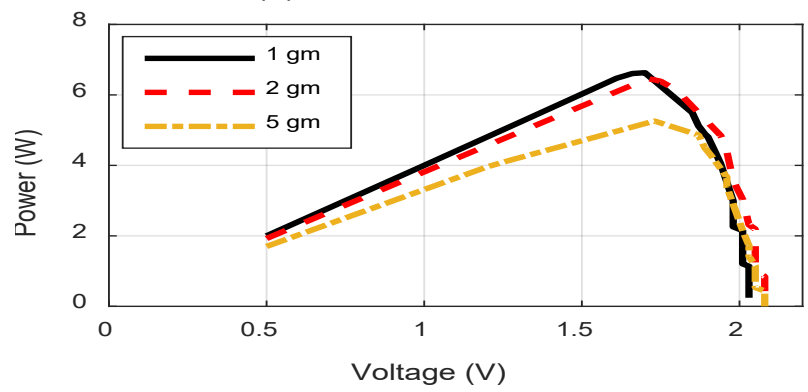

(b) P-V characteristics

Figure 7. I-V and P-V characteristics with Brick furnace dust at $500 \mathrm{~W} / \mathrm{m}^{2}$ 


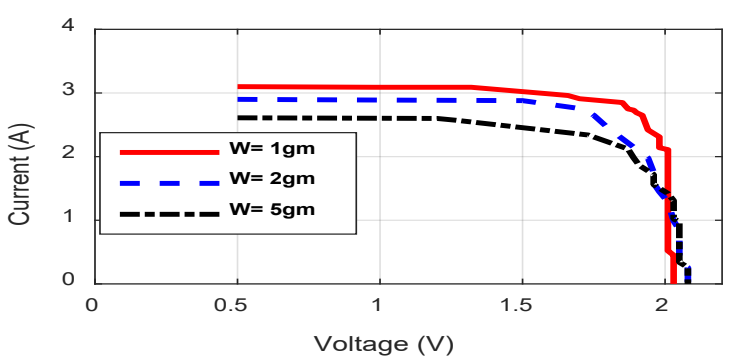

(a) I-V characteristics

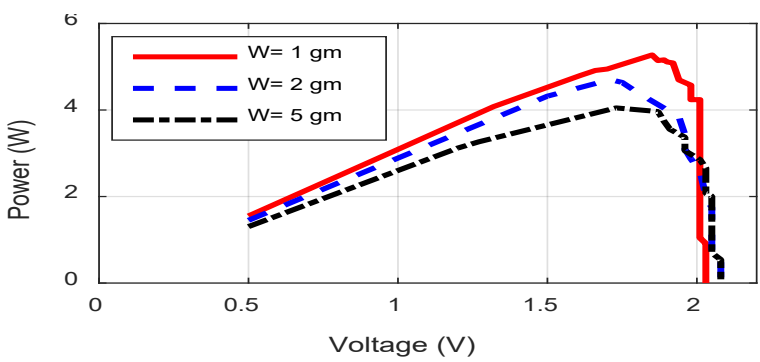

(b) P-V characteristics

Figure 8. I-V and P-V characteristics with Brick furnace dust at $300 \mathrm{~W} / \mathrm{m}^{2}$

Above results are used to calculate the power, FF and other electrical parameters of the PV module for different weights and irradiation levels of $500 \mathrm{~W} / \mathrm{m} 2$ and $300 \mathrm{~W} / \mathrm{m}^{2}$, and depicted in Table 3 as,

Table 3. Electrical performance parameters with Brick furnace dust at $500 / 300 \mathrm{~W} / \mathrm{m}^{2}$

\begin{tabular}{lcccccc}
\hline \multirow{2}{*}{ Parameters } & \multicolumn{6}{c}{ Irradiation levels } \\
\cline { 2 - 7 } & \multicolumn{5}{c}{$500 \mathrm{~W} / \mathrm{m}^{2}$} & \multicolumn{3}{c}{$300 \mathrm{~W} / \mathrm{m}^{2}$} \\
\hline Weight (gm) & 1.0 & 2.0 & 5.0 & 1.0 & 2.0 & 5.0 \\
V OC (V) & 2.08 & 2.07 & 2.05 & 2.05 & 2.04 & 2.02 \\
$\mathrm{I}_{\mathrm{SC}}(\mathrm{A})$ & 4.10 & 3.89 & 3.50 & 3.10 & 2.90 & 2.61 \\
$\mathrm{I}_{\mathrm{m}}(\mathrm{A})$ & 3.98 & 3.78 & 3.04 & 2.85 & 2.75 & 2.34 \\
$\mathrm{~V}_{\mathrm{m}}(\mathrm{V})$ & 1.71 & 1.68 & 1.73 & 1.75 & 1.71 & 1.73 \\
Power (W) & 6.80 & 6.35 & 5.88 & 4.98 & 4.27 & 4.04 \\
Fill Factor & 0.79 & 0.78 & 0.73 & 0.78 & 0.70 & 0.69 \\
\hline
\end{tabular}

*Above tables show the impact of different irradiation levels and different weights of dust on electrical performance.

\subsubsection{Effect of Sugar mill bagasse dust on PV module Performance}

This section discusses about impact of sugar mill bagasse dust on PV performance. Due to this, reduction in the ISC, power and FF of PV module is observed. I-V and P-V characteristics are plotted for brick furnace dust at different weights and irradiation levels. Figure 9-10 show the performance of PV module with sugar mill bagasse dust with the same environmental conditions, similarly as the brick furnace dust.

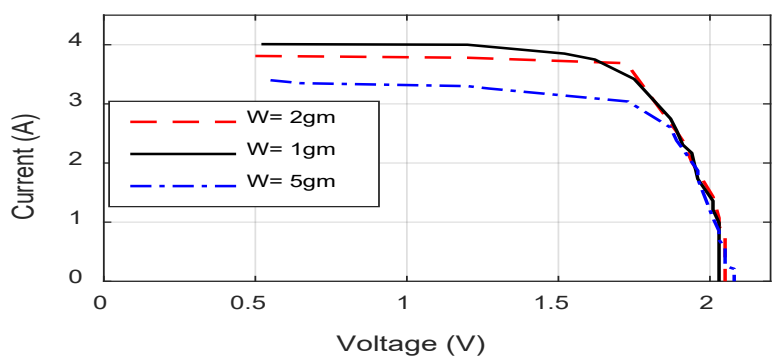

(a) I-V characteristics

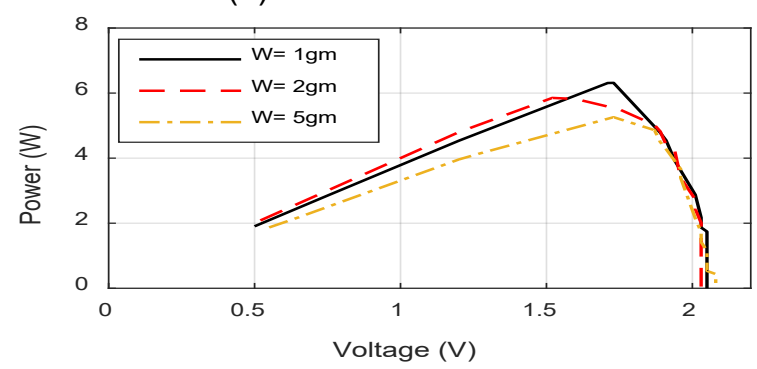

(b) P-V characteristics

Figure 9. I-V and $\mathrm{P}-\mathrm{V}$ characteristics with sugar mill Bagasse dust at $500 \mathrm{~W} / \mathrm{m}^{2}$

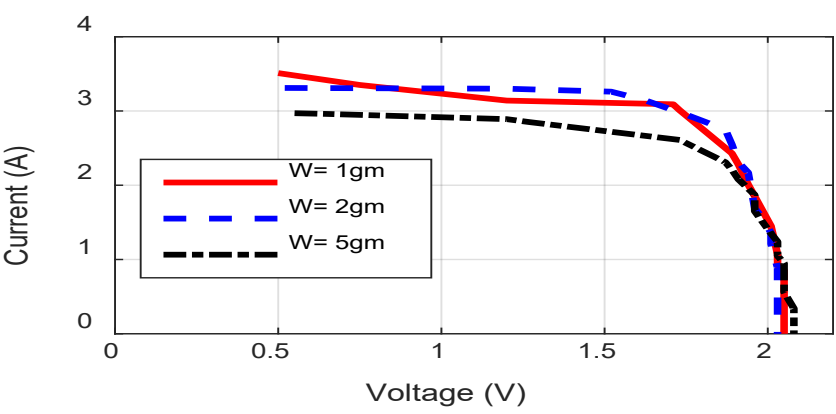

(a) I-V characteristics

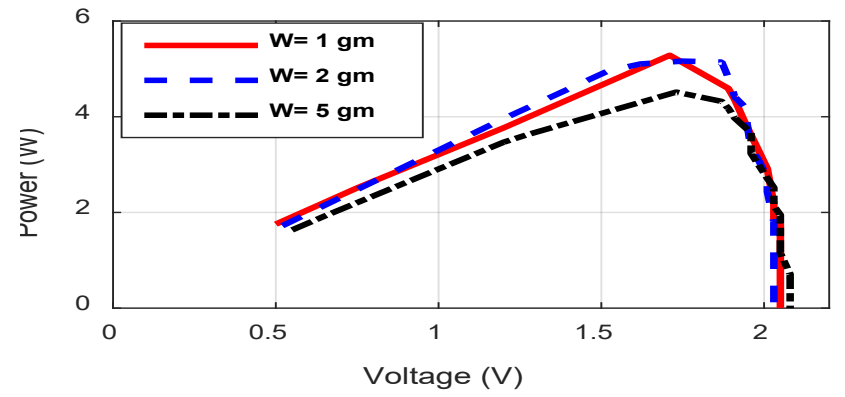

(b) P-V characteristics

Figure 10. I-V and P- V characteristics with sugar mill Bagasse dust at $300 \mathrm{~W} / \mathrm{m}^{2}$

Above electrical performances curves are used to calculate the FF, power and other electrical parameters for the considered PV module. Due to the dust effect, reduction in power is observed with increase in the dust weight. Table 4 shows the calculated FF at different weights and irradiation. 
Table 4. Comparison of parameter with sugar mill Bagasse dust at $500 / 300 \mathrm{~W} / \mathrm{m}^{2}$

\begin{tabular}{lcccccc}
\hline Parameters & \multicolumn{6}{c}{ Irradiation levels } \\
\cline { 2 - 7 } & \multicolumn{3}{c}{$500 \mathrm{~W} / \mathrm{m}^{2}$} & \multicolumn{3}{c}{$300 \mathrm{~W} / \mathrm{m}^{2}$} \\
\hline Weight (gm) & 1.0 & 2.0 & 5.0 & 1.0 & 2.0 & 5.0 \\
Voc (V) & 2.08 & 2.05 & 2.05 & 2.04 & 2.04 & 2.03 \\
Isc (A) & 4.00 & 3.80 & 3.75 & 3.51 & 3.31 & 2.97 \\
Im (A) & 3.75 & 3.65 & 3.04 & 3.09 & 2.89 & 2.45 \\
Vm (V) & 1.62 & 1.64 & 1.68 & 1.68 & 1.65 & 1.66 \\
Power (W) & 6.07 & 5.99 & 4.99 & 5.28 & 4.73 & 4.06 \\
Fill Factor & 0.77 & 0.76 & 0.64 & 0.72 & 0.67 & 0.65 \\
\hline
\end{tabular}

\subsubsection{Effect of natural dust on PV performance}

Natural dust is used here to assess the influence of different weights and irradiation levels on the performance of the PV module. The natural dust affects the PV module performance and electrical parameters. Short circuit current $(\mathrm{Isc}=4.2 \mathrm{~A})$ is more at irradiation $500 \mathrm{~W} / \mathrm{m}^{2}$, whereas, $\mathrm{Isc}=3.51 \mathrm{~A}$ at $300 \mathrm{~W} / \mathrm{m}^{2}$. Figure 11 and 12 show the electrical performance of natural dust on the PV module.

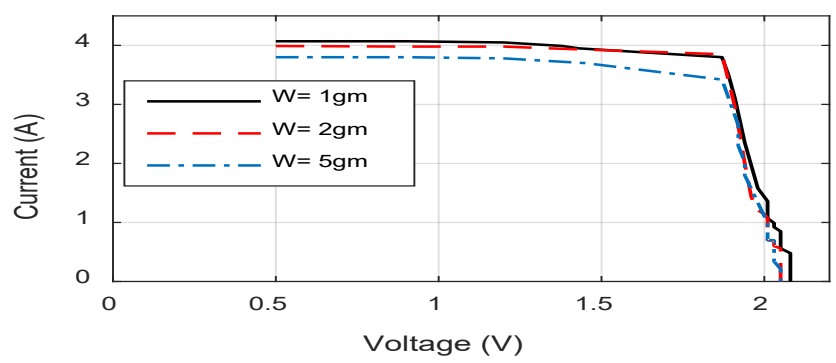

(a) I-V characteristics

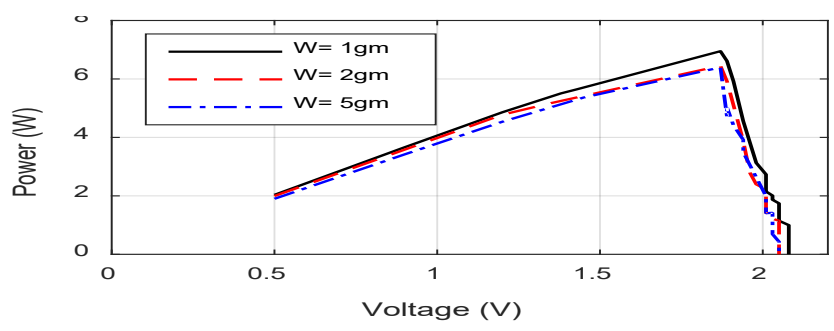

(b) P-V characteristics

Figure 11. I-V and $P-V$ characteristics with Natural dust at $500 \mathrm{~W} / \mathrm{m}^{2}$

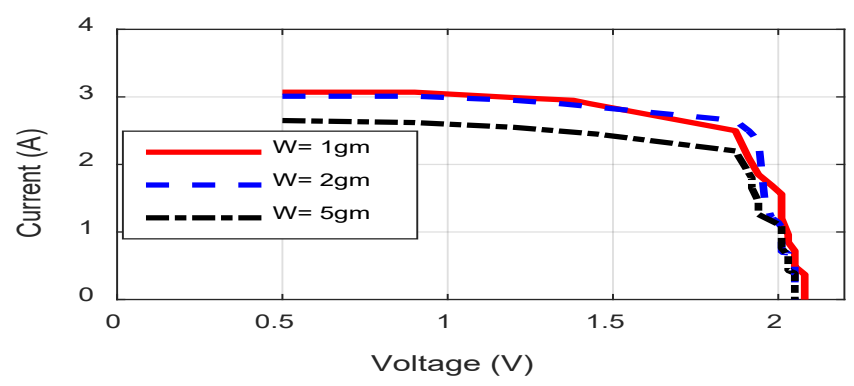

(a) I-V characteristics

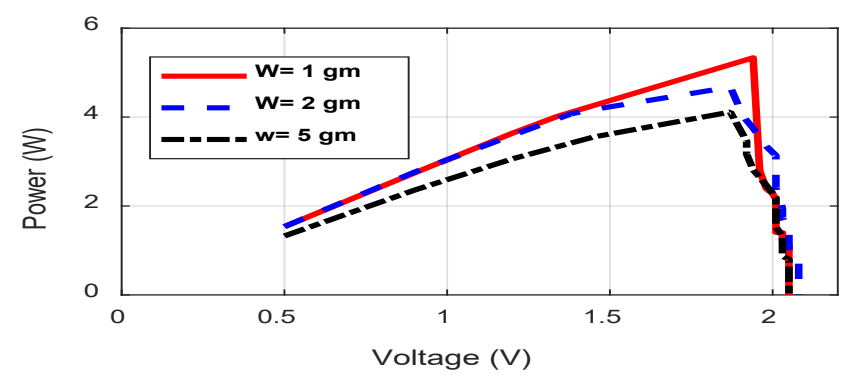

(b) P-V characteristics

Figure 12. I-V and P-V characteristics with Natural dust at $300 \mathrm{~W} / \mathrm{m}^{2}$

Above I-V and P-V curves are used to calculate the FF, maximum power and other electrical parameters of the PV module, depicted in Table 5 as,

Table 5. Comparison of parameters with natural dust at $500 / 300 \mathrm{~W} / \mathrm{m}^{2}$

\begin{tabular}{lcccccc}
\hline Parameters & \multicolumn{5}{c}{ Irradiation levels } \\
\hline & \multicolumn{3}{c}{$500 \mathrm{~W} / \mathrm{m}^{2}$} & \multicolumn{3}{c}{$300 \mathrm{~W} / \mathrm{m}^{2}$} \\
\hline Weight (gm) & 1.0 & 2.0 & 5.0 & 1.0 & 2.0 & 5.0 \\
Woc (V) & 2.05 & 2.03 & 2.01 & 2.03 & 2.03 & 2.02 \\
Isc (A) & 4.20 & 4.15 & 3.88 & 3.07 & 3.01 & 2.82 \\
Im (A) & 3.85 & 3.82 & 3.42 & 2.50 & 2.45 & 2.20 \\
Vm (V) & 1.87 & 1.87 & 1.87 & 1.87 & 1.89 & 1.85 \\
Power (W) & 7.19 & 7.14 & 6.19 & 5.33 & 4.67 & 4.11 \\
Fill Factor & 0.84 & 0.83 & 0.77 & 0.73 & 0.72 & 0.71 \\
\hline
\end{tabular}

\subsection{Effect of dust accumulation on PV performance with reflectors}

In this segment, a study was conducted on the effect of different types of reflector dust on the performance of the solar PV module. Aluminium foil used for the purpose as a reflector, increases the irradiation level of light. Reflectors are covered at all sides of PV module, which increase short circuit current $\left(\mathrm{I}_{\mathrm{SC}}\right)$ and hence power as compared to the without reflector system. The experimental setup for dust with reflector is shown in Figure13 as,

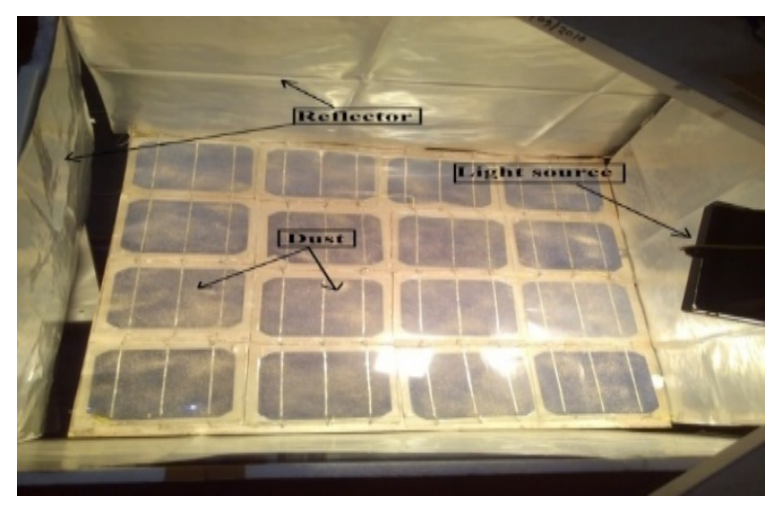

Figure 13. Experimental set up with dust and reflector 


\subsubsection{PV Performance for reflector with Brick} furnace dust

This section discusses about PV performance for Brick furnace dust with reflector. In this case, the short circuit current $\left(\mathrm{I}_{\mathrm{SC}}=6.02 \mathrm{~A}\right)$ and power $(9.88 \mathrm{~W})$ are obtained at irradiation level of $500 \mathrm{~W} / \mathrm{m}^{2}$. Intensity of light decreases the short circuit current and power of the PV module. When dust (weight) accumulation on the PV module increases, the power and short circuit current are impacted. I-V and P-V curves are seen at different rates of weight and radiation. I-V and $\mathrm{P}-\mathrm{V}$ characteristics are shown in Figure 14-15 as,

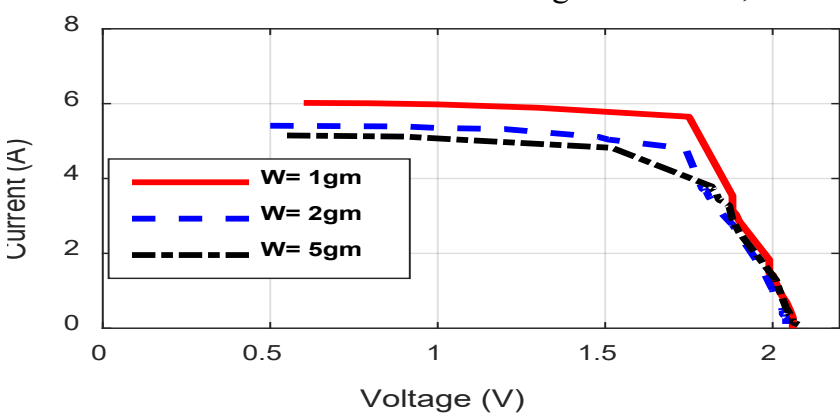

(a) I- V characteristics

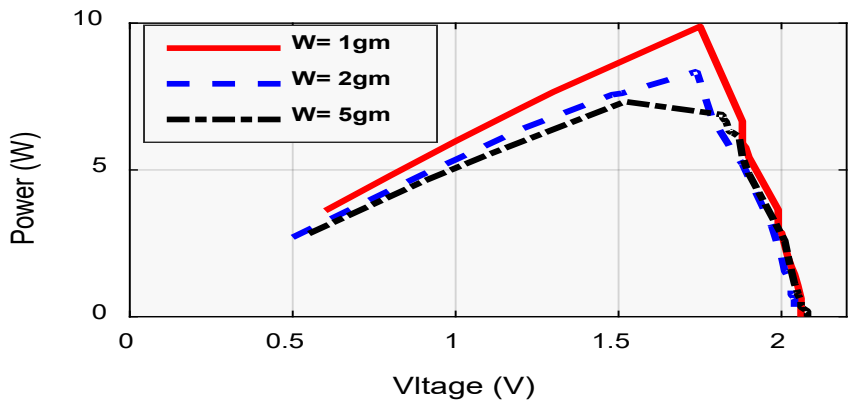

(b) P- V characteristics

Figure 14. I-V and P-V characteristics of Brick furnace dust with reflector at irradiation $500 \mathrm{~W} / \mathrm{m}^{2}$

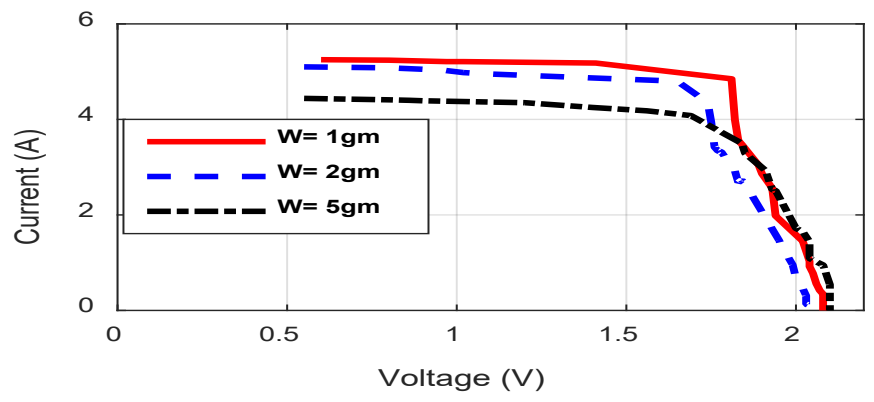

(a) I- V characteristics

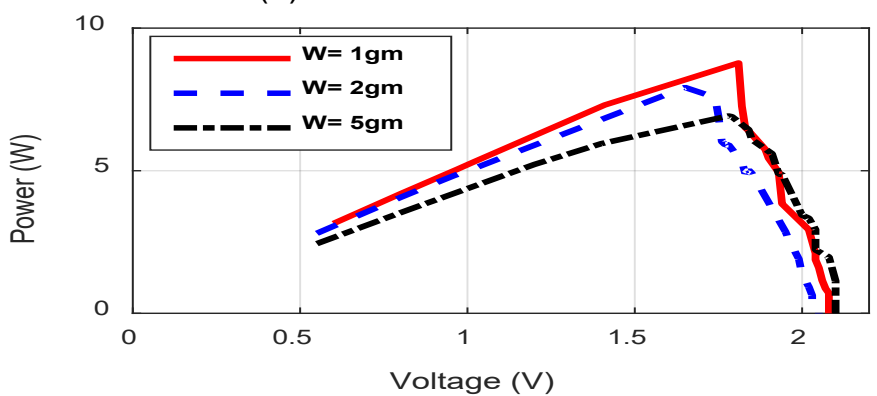

(b) P- V characteristics

Figure 15. I-V and P-V characteristics of Brick furnace dust with reflector at irradiation $300 \mathrm{~W} / \mathrm{m}^{2}$

Using the above results, the FF, power and electrical parameters of the PV module used are calculated. The FF obtained at different weights and irradiation are shown in Table 6 and as

Table 6. Comparison of parameter with Brick furnace dust at 500/300 W/m²

\begin{tabular}{lcccccc}
\hline Parameters & \multicolumn{7}{c}{ Irradiation levels } \\
\hline & \multicolumn{7}{c}{$500 \mathrm{~W} / \mathrm{m}^{2}$} & & $300 \mathrm{~W} / \mathrm{m}^{2}$ \\
\hline Weight (gm) & 1.0 & 2.0 & 5.0 & 1.0 & 2.0 & 5.0 \\
\hline Voc (V) & 2.02 & 2.02 & 2.01 & 2.08 & 2.08 & 2.10 \\
\hline Isc (A) & 6.02 & 5.41 & 5.15 & 5.25 & 5.10 & 4.44 \\
\hline Im (A) & 5.65 & 4.80 & 4.82 & 4.83 & 4.80 & 4.08 \\
\hline Vm (V) & 1.75 & 1.75 & 1.52 & 1.81 & 1.65 & 1.69 \\
\hline Power (W) & 9.88 & 8.35 & 7.32 & 8.74 & 7.92 & 6.89 \\
\hline Fill Factor & 0.79 & 0.75 & 0.68 & 0.80 & 0.76 & 0.73 \\
\hline
\end{tabular}

\subsubsection{Effect of Sugar mill Bagasse dust on PV module performance using reflector}

In this section sugar mill bagasse dust is used to get accumulated on the PV module. Decrease in the short circuit current is observed $\left(\mathrm{I}_{\mathrm{SC}}=5.88 \mathrm{~A}, 5.23 \mathrm{~A}, 5.15 \mathrm{~A}\right)$ for weights (1gm, $2 \mathrm{gm}, 5 \mathrm{gm})$ respectively at $500 \mathrm{~W} / \mathrm{m}^{2}$. When irradiation is reduced to $300 \mathrm{~W} / \mathrm{m}^{2}$, the $\mathrm{I}_{\mathrm{SC}}$ is further decreased as $(5.20 \mathrm{~A}$, $4.62 \mathrm{~A}, 4.50 \mathrm{~A})$ respectively for the above mentioned weights and hence power of module decreases with increase in weight. The performance of the I-V and P-V characteristics are shown in Figure15-16 as,

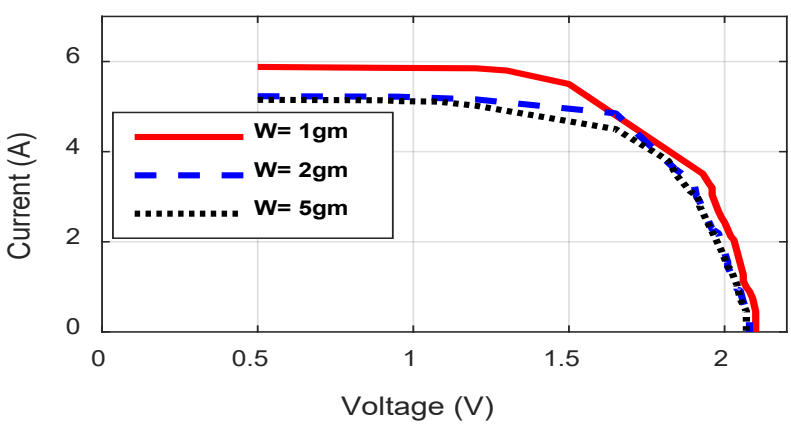

(a) I- V characteristics

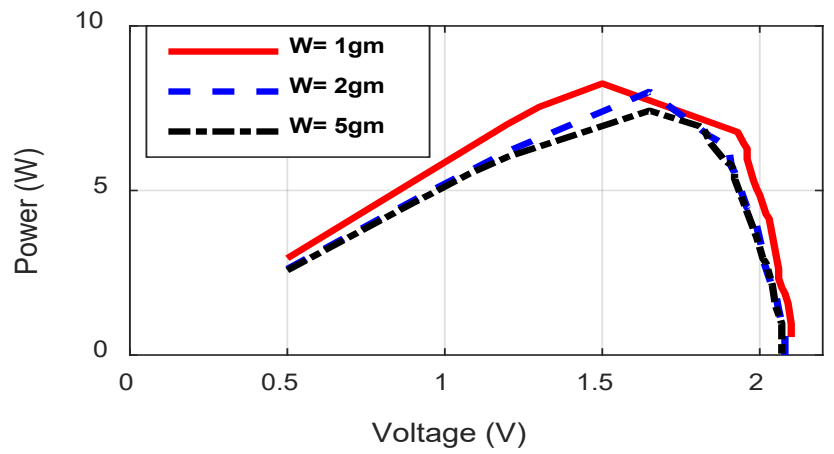

EAl Endorsed Transactions on Energy Web 052020 - 072020 | Volume 7 | Issue 28 | e10 
(b) P- $V$ characteristics

Figure 15. I-V and P-V characteristics of sugar mill bagasse dust with reflector at $500 \mathrm{~W} / \mathrm{m}^{2}$

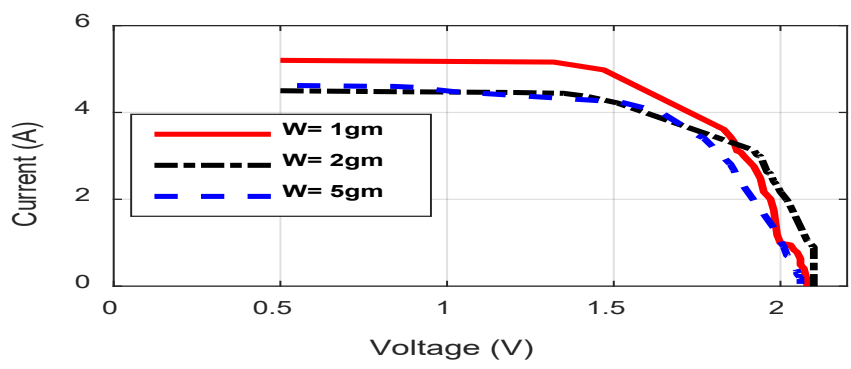

(a) I- V characteristics

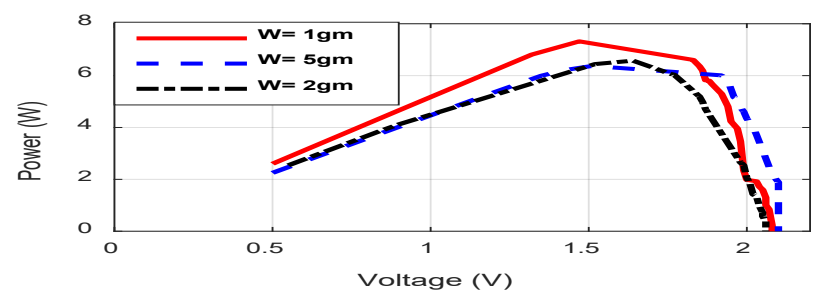

(b) P- V characteristics

Figure 16. I-V and P-V characteristics of Sugar mill bagasse dust with reflector at $300 \mathrm{~W} / \mathrm{m}^{2}$

Above results are used to calculate the $\mathrm{FF}$, power and electrical parameter of the considered PV module; and are shown in Table 7 as,

Table 7. Comparison of parameter with Sugar mill bagasse dust at $500 / 300 \mathrm{~W} / \mathrm{m}^{2}$

\begin{tabular}{lcccccc}
\hline Parameters & \multicolumn{5}{c}{ Irradiation levels } \\
\cline { 2 - 7 } & \multicolumn{3}{c}{$500 \mathrm{~W} / \mathrm{m}^{2}$} & \multicolumn{3}{c}{$300 \mathrm{~W} / \mathrm{m}^{2}$} \\
\hline Weight (gm) & 1.0 & 2.0 & 5.0 & 1.0 & 2.0 & 5.0 \\
Voc (V) & 2.08 & 2.08 & 2.06 & 2.08 & 2.08 & 2.10 \\
Isc (A) & 5.88 & 5.23 & 5.15 & 5.20 & 4.62 & 4.50 \\
Im (A) & 5.75 & 4.85 & 4.50 & 5.10 & 4.24 & 4.38 \\
Vm (V) & 1.61 & 1.65 & 1.66 & 1.51 & 1.49 & 1.42 \\
Power (W) & 9.22 & 8.02 & 7.42 & 7.70 & 6.57 & 6.37 \\
Fill Factor & 0.74 & 0.73 & 0.71 & 0.71 & 0.69 & 0.67 \\
\hline
\end{tabular}

\section{Performance comparison of all the considered dust cases}

In this section, performance of PV module under different test conditions is analysed and compared to obtain the inference of the study.

\subsection{Comparative analysis of PV module for dust accumulation without reflector}

The sugar baggase dust affects the efficiency $(\eta)$ and deteriorating with increment in weight. It is evident from Table 8 that FF and efficiency both decrease with increase in weight of dust as,

Table 8. Comparison of FF and $\eta$ for different dusts and weights

\begin{tabular}{|c|c|c|c|c|c|c|c|}
\hline \multirow[t]{2}{*}{$\begin{array}{l}\text { Irradiation } \\
\mathrm{W} / \mathrm{m}^{2}\end{array}$} & \multirow[t]{2}{*}{$\begin{array}{l}\text { Weight } \\
\text { of dust }\end{array}$} & \multicolumn{2}{|c|}{$\begin{array}{c}\text { Natural } \\
\text { dust }\end{array}$} & \multicolumn{2}{|c|}{$\begin{array}{c}\text { Brick } \\
\text { furnace } \\
\text { dust }\end{array}$} & \multicolumn{2}{|c|}{$\begin{array}{c}\text { Sugar } \\
\text { bagasse } \\
\text { dust }\end{array}$} \\
\hline & & $\mathrm{FF}$ & $\begin{array}{c}\eta \\
(\%)\end{array}$ & $\overline{F F}$ & $\begin{array}{c}\eta \\
(\%)\end{array}$ & FF & $\begin{array}{c}\eta \\
(\%)\end{array}$ \\
\hline \multirow{3}{*}{500} & $1 \mathrm{gm}$ & 0.74 & 4.04 & 0.74 & 4.02 & 0.74 & 3.88 \\
\hline & $2 \mathrm{gm}$ & 0.73 & 3.94 & 0.73 & 3.85 & 0.73 & 3.70 \\
\hline & $5 \mathrm{gm}$ & 0.70 & 3.52 & 0.70 & 3.32 & 0.73 & 3.23 \\
\hline \multirow{3}{*}{300} & $1 \mathrm{gm}$ & 0.72 & 5.76 & 0.76 & 5.52 & 0.71 & 5.40 \\
\hline & $2 \mathrm{gm}$ & 0.71 & 5.31 & 0.75 & 5.02 & 0.68 & 4.90 \\
\hline & $5 \mathrm{gm}$ & 0.70 & 4.47 & 0.73 & 4.29 & 0.65 & 4.36 \\
\hline
\end{tabular}

In Table 9, the performance of PV module is investigated for the variable thickness of considered dust samples e.g. Natural, Brick furnace and sugar bagasse dust. The solar irradiations are considered as $500 \mathrm{~W} / \mathrm{m}^{2}$ and $300 \mathrm{~W} / \mathrm{m}^{2}$ for the extensive study. Maximum power of clean panel without dust is $5.69 \mathrm{~W}$ at $300 \mathrm{~W} / \mathrm{m}^{2}$ as,

Table 9. Comparison of $V_{m}, I_{m}$ and $P$ with different weights of dust at $500 / 300 \mathrm{~W} / \mathrm{m}^{2}$

\begin{tabular}{cccccc|cccc|cccc}
\hline Dust weight Irradiation & \multicolumn{4}{c}{ Natural dust } & \multicolumn{4}{c}{ Brick furnace dust } & \multicolumn{4}{c}{ Sugar bagasse dust } \\
\hline & & $\mathrm{V}_{\mathrm{m}}$ & $\mathrm{I}_{\mathrm{m}}$ & $\mathrm{P}$ & $\mathrm{P}_{\text {loss }}(\%)^{*}$ & $\mathrm{~V}_{\mathrm{m}}$ & $\mathrm{I}_{\mathrm{m}}$ & $\mathrm{P}$ & $\mathrm{P}_{\text {loss }}(\%)$ & $\mathrm{V}_{\mathrm{m}}$ & $\mathrm{I}_{\mathrm{m}}$ & $\mathrm{P}$ & $\mathrm{P}_{\text {loss }}(\%)$ \\
& & $(\mathrm{V})$ & $(\mathrm{A})$ & $(\mathrm{W})$ & & $(\mathrm{V})$ & $(\mathrm{A})$ & $(\mathrm{W})$ & & $(\mathrm{V})$ & $(\mathrm{A})$ & $(\mathrm{W})$ & \\
\cline { 2 - 14 } $1 \mathrm{gm}$ & 1.60 & 3.92 & 6.27 & -1.72 & 1.61 & 3.88 & 6.24 & -2.19 & 1.62 & 3.75 & 6.07 & -4.85 \\
$2 \mathrm{gm}$ & $500 \mathrm{~W} / \mathrm{m}^{2}$ & 1.62 & 3.78 & 6.12 & -4.07 & 1.65 & 3.62 & 5.97 & -6.42 & 1.60 & 3.54 & 5.74 & -10.03 \\
$5 \mathrm{gm}$ & & 1.68 & 3.25 & 5.46 & -14.42 & 1.69 & 3.05 & 5.15 & -19.27 & 1.68 & 2.99 & 5.02 & -21.31 \\
\hline $1 \mathrm{gm}$ & 1.68 & 3.35 & 5.36 & -5.79 & 1.78 & 2.89 & 5.14 & -9.66 & 1.63 & 3.09 & 5.03 & -11.59 \\
$2 \mathrm{gm}$ & $300 \mathrm{~W} / \mathrm{m}^{2}$ & 1.62 & 3.05 & 4.94 & -13.18 & 1.70 & 2.75 & 4.67 & -17.92 & 1.58 & 3.89 & 4.50 & -20.91 \\
$5 \mathrm{gm}$ & 1.70 & 2.45 & 4.16 & -26.88 & 1.73 & 2.31 & 3.99 & -29.87 & 1.66 & 2.45 & 4.06 & -28.64 \\
\hline
\end{tabular}

* Minus sign indicates \% decrease in maximum power with respect to the clean panel $(6.38 \mathrm{~W})$ 


\subsection{Comparative analysis of $P V$ module for dust accumulation with reflector}

In this investigation of dust accumulation with reflector, two types of dust samples e.g. brick furnace dust and sugar bagasse dust are considered only. The solar irradiation levels are considered as $500 \mathrm{~W} / \mathrm{m}^{2}$ and $300 \mathrm{~W} / \mathrm{m}^{2}$ for the extensive comparative study. A comparison of $\mathrm{FF}$ and efficiency for different dusts and weights with reflector at $500 / 300 \mathrm{~W} / \mathrm{m}^{2}$ irradiation level is done and the obtained performance parameters are depicted in Table 10 as,

Table 10. Comparison of FF and efficiency for different dust samples and weights with reflector at $500 / 300 \mathrm{~W} / \mathrm{m}^{2}$

\begin{tabular}{ccccc|cccc}
\hline Dust samples & \multicolumn{1}{c}{ Brick furnace dust } & \multicolumn{1}{c}{ Sugar bagasse dust } & Brick furnace dust & Sugar bagasse dust \\
\hline Irradiation level & \multicolumn{9}{c}{$500 \mathrm{~W} / \mathrm{m}^{2}$} \\
\hline Weight of dust & FF & $\eta(\%)$ & FF & $\eta(\%)$ & FF & $\eta(\%)$ & FF & $\eta(\%)$ \\
\hline 1gm & 0.79 & 6.33 & 0.74 & 5.93 & 0.79 & 9.39 & 0.71 & 8.27 \\
2gm & 0.75 & 5.38 & 0.73 & 5.17 & 0.76 & 8.51 & 0.68 & 7.06 \\
$5 \mathrm{gm}$ & 0.68 & 4.72 & 0.69 & 4.78 & 0.73 & 7.31 & 0.67 & 6.82 \\
\hline
\end{tabular}

\section{Conclusion}

The aim of this paper was to develop the low cost experimental setup using Arduino-UNO interfaced with MATLAB based GUI platform to obtain the I-V and P-V characteristics for the PV module's comprehensive performance investigation. The system developed was intended for data acquisition, monitoring, display of characteristics and evaluation of the impact of considered dust samples on the PV module. The main points of this experimental study are below and the assessment of PV system is carried out in terms of $\mathrm{V}_{\mathrm{OC}}$, $\mathrm{I}_{\mathrm{SC}}$, maximum power, efficiency and FF as,

- The improvements in the efficiency and FF of PV module are observed as $6.01 \%$ and 0.85 respectively for the clean $\mathrm{PV}$ module with reflector as compared higher as $3.70 \%$ and 0.80 for clean PV module without reflector at $500 \mathrm{~W} / \mathrm{m}^{2}$.

- The sugar mill bagasse dust sample reduced PV module performance in terms of $\mathrm{FF}$ as 0.77 as compare to different dust samples such as brick furnace (FF- 0.79) and natural dust sample (FF0.84 ) without reflectors at $1 \mathrm{gm}$ dust and $500 \mathrm{~W} / \mathrm{m}^{2}$ irradiance.

- The sugar mill bagasse dust sample reduced PV module performance in terms of $\mathrm{FF}$ as 0.74 as compare to brick furnace dust sample as 0.79 with reflector at $1 \mathrm{gm}, 500 \mathrm{~W} / \mathrm{m}^{2}$.

- The comprehensive study of dust accumulation effect on solar PV system is carried out. Present study is helpful for the online characterization of PV module, the cost of developed system is very low as compared the commercial available system. It is a novel contribution at the laboratory based experimental platform for the new beginners in this area.

\section{Acknowledgements}

The authors are very thankful to the higher academic authority of Gautam Buddha University, Greater Noida for providing a good research environment and resources. During the experimental study, there is no conflict of internet among all the authors.

\section{References}

[1] Fuentes, M., Vivar, M., Burgos, J. M., Vacas, J. A. (2014) Design of an accurate, low-cost autonomous data logger for PV system monitoring using Arduino that complies with IEC standards. Solar Energy 130: 529-543.

[2] Reguera, P., Garcia, D., Dominguez, M., Prada, M. A., Alonso, S. (2015) A low cost open source hardware in control education- Case study: Arduino -feedback ms 150. Science 48(29): 117-122.

[3] Ikhsan, M., Purwadi, A., Hariyanto, N., Heryana, N., Haroen, Y. (2013) Study of renewable energy sources capacity and loading using data logger for sizing of solar wind hybrid power system. Procedia Technology 11: 10481053.

[4] Ferdoush, S., Li, X. (2014) Wireless sensors network system design using raspberry pi and Arduino for environmental monitoring applications. Procedia Computer Science 34: 103-110.

[5] Ali, A. S., Zanzinger, Z., Debose, D., Stephens, B. (2016) Open sources building science sensors: a low cost Arduino based platform for long term indoor environment data collection. Building and Environment 100: 114-126.

[6] Tanesab, J., Parlevliet, D., Whale, J., Urmee, T. (2016) Dust effect and its economic analysis on PV modules deployed in a temperate climate zone. Energy Procedia 100: 65-68.

[7] Appels, R., Lefevre, B., Herteleer, B., Goverde, H., Beerten, A., Paesen, R., Medts, K.D., Driesen, J., Poortmans, J. (2013) Effect of soiling on photovoltaic modules. Solar Energy 96: 283-291. 
[8] Adinoyi, M. J., Said, S. A. M. (2013) Effect of dust accumulation on the power outputs of solar photovoltaic modules. Renewable Energy 60: 633-636.

[9] Abderrezek, M., Fathi, M. (2017) Experimental study of the dust effect on Photovoltaic panels' energy yield. Solar Energy 142: 308-320.

[10] Mekhilef, S., Saidur, R., Kamalisarvestani, M. (2012) Effect of dust, humidity and air velocity on efficiency of photovoltaic cells. Renewable Energy 16: 2920-2925.

[11] Mani, M., Pillai, R. (2010) Impact of dust on solar photovoltaic performance: research status challenges and recommendations. Renewable Energy 14: 3124-3131.

[12] Gaun, Y., Zhang, H., Xiao, B., Zhou, Z., Yan, Xuzhou. (2017) In situ investigation of the effect of dust deposition on the performance of polycrystalline silicon photovoltaic modules. Renewable Energy 101: 1273-1284.

[13] Khatib, T., Kazem, H., Sopian, K., Buttinger, F., Elmenreich, W., Albusaidi, A. S. (2013) Effect of dust deposition on the performance of multi crystalline photovoltaic modules based on experimental measurements. International Journal of Renewable Energy and Energy Research 3(4): 850-853.

[14] El-nashar, A. M. (2009) Seasonal effect of dust deposition on a field of evacuated tube collectors on the performance of a solar desalination plant. Desalination 239: 66-81.

[15] Said, S. A. M., Walwil, H. M. (2014) Fundamental studies on dust fouling effects on PV module performance. Solar Energy 107: 328-337.

[16] Shehri, A. A., Parrott, B., Carrasco, P., Saiari, H. A., Taie, I. (2016) Impact of dust deposition and brush based dry cleaning on glass transmittance for PV modules applications. Solar Energy 135: 317-324.

[17] Sulaiman, S. A., Hussain, H. H., Razali, M. S. I. (2011) Effects of dust on the performance of PV panels. Science Engineering and Technology 5(10): 2088-2033.
[18] Omara, Z. M., Kabeel, A. E., Abdullah, A. S. (2017) A review of solar still performance with reflectors. Renewable and Sustainable Energy Reviews 68: 638-649.

[19] Lo, C. K., Lim, Y. S., Rahman, F. A. (2015) New integrated simulation tool for the optimum design of bifacial solar panel with reflectors on a specific site. Renewable Energy 81: 293-307.

[20] Garcia, A. F., Alvarez-Rodrigo, L., Martinez-Arcos, L., Aguiar, R., Marquez-payes, J. M. (2014) Study of different cleaning methods for solar reflectors used in CSP plants. Energy Procedia 49: 80-89.

[21] Pavlovic, Z. T., Kostic, L. T., (2015) Variation of reflected radiation from all reflectors of flat plate solar collector during a year. Energy 80: 75-84.

[22] Lim, Y. S., Lo, C. K., Kee, Y., Ewe, H. T., Faidz, A. R., (2014) Design and evaluation of passive concentrator and reflector systems for bifacial solar panel on a highly cloud region. Renewable Energy 63: 415-425.

[23] Minemoto, T., Murozono, M., Yamaguchi, Y., Takakur, H., Hamakawa, Y. (2006) Design strategy and development of spherical silicon solar cell with semi- concentration reflector system. Solar Energy and cells 90: 3009-3013.

[24] Andrews, R. W., Pollard, A., Pearce, J. M., (2015) Photovoltaic systems performance enhancement with nontracking planar concentrators: experimental results and bidirectional reflectors function (BDRF) based modelling. IEEE Journal of Photovoltaics 5(6): 1626- 1635. 